\title{
THE NEURAL CIRCULATION. THE USE OF ANALOGY IN MEDICINE*
}

\author{
by
}

\author{
EDWIN CLARKE**
}

\section{INTRODUCTION}

THE HISTORY of medicine can be likened to a length of patterned fabric, a long tapestry stretching from Prehistory up to the present day, which is being continuously added to. On it are woven the ideas responsible for medicine's advancement, along with factors that influenced their origin and survival: technological, social, religious, financial, political, and others. There are also the social aspects of medicine per se and, in the foreground, the patient.

Inspection of an earlier part of the tapestry, say the seventeenth century, reveals that only some pieces of the pattern can be identified. These are the ideas that are still accepted today, and they are therefore, judged to be correct. Those that are not recognized, are the ideas that have not survived and frequently they are given judgment-loaded epithets such as "odd", "curious", or even "ridiculous", and in the light of today's knowledge they are said to be wrong. And yet it is clear that they are intimately woven into the overall pattern and they cannot, therefore, be neglected. The same is true of medicine today, which includes concepts that in the future may turn out to be incorrect. However, for the moment contemporary weavers are incorporating them into the growing end of the tapestry of time.

When dealing with historical material, there are two cardinal sins that must be resisted. First, modern knowledge must not be used to assess the past. Thus, the seventeenth-century part of the tapestry cannot be appreciated by peering at it from today's end. One has to move back along its length, cast off all modern learning,

*Based on the Fitz-Patrick Lecture for 1977 presented at the Royal College of Physicians of London on 7 December 1977.

Dr. Thomas Fitz-Patrick (1832-1900) was a Member of the College, but never a Fellow, and, as the College's distinguished Harveian Librarian, Dr. Charles Newman, pointed out in his Unofficial Fitz-Patrick Lecture of 28 February 1958, Dr. Fitz-Patrick should be one of the patron saints of Members. He was imbued with learning and linguistic skills, but although he is said to have been much concerned with ". . . the advancement of the study of medical history ..." (J. F. Payne, The Fitzpatrick Lecture for 1903. English medicine in the Anglo-Saxon times, Oxford, Clarendon Press, 1904, p. 1.), in his writings he reveals little or no interest in the history of medicine. There are, however, two other persons to remember with gratitude. One is Mrs. Fitz-Patrick, to whose munificence this Lecture owes its existence. Wishing to honour the memory of her late husband in the College, she consulted Dr., later Sir, Norman Moore, an intimate friend of her late husband and President of the College from 1918 to 1922 . He suggested a lectureship in the history of medicine, the first being given in 1903 .

**Edwin Clarke, M.D., F.R.C.P., Director of the Wellcome Institute for the History of Medicine, 183 Euston Road, London NW1 2BP. 


\section{Edwin Clarke}

and try to analyse and understand the concept, and to comprehend the individuals, as they actually are in their section of the tapestry. Second, earlier workers in the field of medicine must not be judged harshly just because, as Mary Hesse puts it, to present-day observers they seem to be doing modern science badly. ${ }^{1}$ In fact, in some cases they were not moving towards today's position at all, nor were they employing modern scientific methods and assumptions. Sometimes they were more concerned with metaphysical or even mythological systems, and this is more obvious the further one goes back in time. It follows that no-one today is in a position to judge past ideas to be "wrong" just because they do not agree with modern opinions. Some are almost certainly so, but with others where there is less certainty, perhaps a blander term such as "discarded", "superseded", or the like should be used. In any case the main concern should be to understand an idea rather than to criticize it and to admonish its creator. After all, those who appear to be contributing to medicine today are equally at risk and may well be censured by their successors if their researches turn out eventually to be unacceptable.

It is a discarded theory that forms the basis of this Lecture, the neural circulation or the circulation in the nerves. But like others of its kind, although it has not survived to the present day, nevertheless its influence can be traced long after its death. Here then is another reason for not neglecting entirely the superseded ideas of medicine.

\section{THE ANALOGY}

The theory of neural circulation illustrates the use of the analogy, which is employed in the exploration and establishment of scientific concepts, and this technique in its simplest form as applied to medicine and biology must, therefore, be examined. In the New Oxford dictionary, one of the definitions describes it as "Resemblance of form or function between organs which are essentially different (in different species) ...."2 Thus, Sir Humphry Davy in 1814 wrote: "Linnaeus, whose lively imagination was continually employed in endeavours to discover analogies between animal and vegetable systems, conceived that 'the pith performed for the plant the same functions as the brain and nerves in animated beings'. ..."s

It is likely that philosophers might not agree with the use of the term "analogy" in some of the examples to be cited below. It is true that on occasions "similitude", "comparison", or "resemblance" may be more appropriate. In very few, if any, of the cases to be mentioned has the logical argument by analogy been carried out step by step in the way that the philosopher demands. Thus, most examples are where the analogy has been "noticed", "perceived", or "suggested", and where there was no formal reasoning on the lines of the logical paradigm of an argument from analogy.

1 Mary B. Hesse, Forces and fields. The concept of action at a distance in the history of physics, London, Nelson, 1961, p. 29. She is referring here specifically to the Greek natural philosophers.

James A. H. Murray (editor), A new English dictionary on historical principles, Vol. 1.A and B. Part 1.A., Oxford, Clarendon Press, 1888, p. 304. This is the ninth meaning and relates to natural history.

Elements of agricultural chemistry, in a course of lectures for the Board of Agriculture, London, Longman, etc., 1813, p. 55. 


\section{The neural circulation}

It has been suggested that in these cases the term "analogical act" should be used."

The analogy as a philosophical term will not be considered here, nor its use in the physical sciences, ${ }^{5}$ where it has been said that having climbed to the abstract mathematics by means of the analogy, the analogical ladder can then be thrown away. ${ }^{6}$ Nor will mention be made of the analogy in chemistry, ${ }^{7}$ or logic.

Basically the analogy is an aid to discovery, by suggesting clues and hypotheses. It is a method of using the known to elucidate the unknown, but it is a resemblance between the relationship of things, rather than between the things themselves. Thus a bodily organ of known structure has a certain function. Another organ with similar structure, by analogy may also have this function. The analogy, being like a guide post, then generates hypotheses, with the prospect that ensuing investigations may shed light on the known as well as on the unknown, and, in this case, also on the function. Many significant and revolutionary advances in science have been made by individuals who have detected analogies not seen by others, and some analogical acts have been strokes of genius, resulting in a new basis for further development of a science.

An analogy never proves anything and it can even be dangerous if it cannot be verified. Moreover, if it masquerades in the place of explanation it is valueless. ${ }^{8}$ But even an erroneous analogy may be profitable, as was the case with Malpighi. In his anatomical studies of animals, he encountered insuperable difficulties, and, therefore, looked instead at their analogues, the plants, thereby founding the science of plant anatomy. ${ }^{9}$

Analogies have been used in medicine since the Ancient Greeks. ${ }^{10}$ For example,

-W. H. Leatherdale, The role of analogy, model and metaphor in science, Amsterdam, NorthHolland Publishing Co., 1974, p. 14.

${ }^{5}$ See, Mary B. Hesse, Models and analogies in science, London, Sheed \& Ward, 1963; and idem, op. cit., note 1 above; and idem, Science and the human imagination. Aspects of the history and logic of physical science, London, SCM Press, 1954; Peter Achinstein, Concepts of science. A philosophical analysis, Baltimore, Md., The Johns Hopkins University Press, 1968, pp. 203-209.

- Hesse (1954), op. cit., note 5 above, p. 143. See also, Joseph Turner, 'Maxwell on the method of physical analogy', Brit. J. phil. Sci., 1955, 6: 226-238.

7 Eduard Farber, 'Chemical discoveries by means of analogies', Isis, 1950, 41: 20-26.

- It will be shown later how a false analogy was partly responsible for leading Malpighi and many others into error. As Hans Reichenbach stated (The rise of scientific philosophy, Berkeley, University of California Press, 1951, p. 11): ". . . Pernicious errors through false analogies have been the philosopher's disease at all times".

- Agnes Arber, 'The biologist's use of analogy', in, The mind and the eye. A study of the biologist's standpoint, Cambridge University Press, 1964, pp. 32-44, see p. 42: See also her essay, 'Analogy in the history of science', in, M. F. Ashley Montagu (editor), Studies and essays in the history of science and learning offered in homage to George Sarton on the occasion of his sixtieth birthday 31st August 1944, New York, H. Schuman, 1946, pp. 219-233. Another excellent contribution to the study of the analogy in biology is Philip C. Ritterbush's, 'The triumph of botanical analogy', in his, Overtures to biology. The speculations of eighteenth-century naturalists, New Haven, Yale University Press, 1964, pp. 109-157. See also, Georges Canguilhem, 'The role of analogies and models in biological discovery', in, A. C. Crombie (editor), Scientific change, etc., London, Heinemann, 1963, pp. 507520 and 590-596. An earlier work, by James Parsons, (Philosophical observations on the analogy between the propagation of animals and that of vegetables: etc., London, for C. Davies, 1752) is also of interest.

${ }^{10}$ G. E. R. Lloyd, Polarity and analogy. Two types of argumentation in early Greek thought, Cambridge University Press, 1966, 'Part Two: Analogy', pp. 172-420. The Hip pocratic corpus is discussed on pp. 345-360. 


\section{Edwin Clarke}

the Hippocratic physicians of the fifth century B.c. noted that a skin ulcer produced pus, blood, and tissue debris. If these appeared in the urine, by analogy the patient must have an ulcer of the bladder. ${ }^{11}$ Other Greeks used the analogy in attempts to understand the movement of body fluids, the theories of conception, of respiration, and of nutrition, the formation of bladder stones, and the varieties of congestion. ${ }^{12}$

In medicine and biology, mechanical or chemical analogies are especially useful, and they were very common in the seventeenth century. Thus Descartes was concerned with analogies between mechanical and physiological action, and Willis and Mayow with chemical and physiological action. Fruitful analogies between physiological processes and physical phenomena, such as rainfall, earthquakes, and cosmology, were also employed, and the analogy became the corner-stone of comparative anatomy.

It has, in fact, been claimed that in medicine and biology it is almost possible to trace historical progress by observing how analogies have helped discoveries. ${ }^{13}$ Examples are plentiful. Thus, in neurophysiology there are many, including the following: nerve transmission and electric current; the brain and the telephone switchboard or the electronic calculating machine; the eye and the camera; the eye and the photographic plate; and the many analogies employed to understand memory.

The value of analogy in clinical medicine is also considerable, as Murphy points out in his recent book The logic of medicine, where he discusses its relations to etiology, treatment, and measurement. ${ }^{14}$ However, no attempt has so far been made to survey historically the use of the analogy in the evolution of medicine. In the ensuing discussion the various uses of analogy will be noted, further to illustrate their value in medicine.

\section{THE NEURAL CIRCULATION}

\section{Henricus Regius (1598-1679)}

The neural circulation was first proposed by a Dutchman, Hendrik de Roy, better known as Henricus Regius ${ }^{15}$ (Figure 1). He was professor of medicine in the University of Utrecht, and was described by Descartes as "a man of most subtle and perceptive

11 Aphorisms, in, Hippocrates with an English translation by W. H. S. Jones, Litt.D. . ., London' W. Heinemann, 1931, Volume 4, pp. 156 and 157: "LXXXI. If the urine contain blood, pus and scales, and its odour be strong, it means ulceration of the bladder". Similarly Aphorism LXXVIII, ibid., "When a patient has a spontaneous discharge of blood and urıne, it indicates the breaking of a small vein in the kidney".

${ }_{12}$ W. A. Heidel, The heroic age of science, Baltimore, Williams \& Wilkins, 1933, pp. 139-152. Mary Hesse's article on 'Aristotle's logic of analogy', Philosophical Quarterly, 1965, 15: 328-340, is of relevance here, as is Jonathan Barnes, et al. (editors), Articles on Aristotle, 1. Science, London, Duckworth, 1975, pp. 175-182, where L. Bourgey discusses 'Observation and experiment in analogical explanation'.

${ }_{13}$ Norwood Russell Hansen, Perception and discovery. An introduction to scientific inquiry, San Francisco, Freeman, Cooper, 1969, p. 317.

14 Edmond A. Murphy, The logic of medicine, Baltimore, Md., The Johns Hopkins University Press, 1976.

${ }_{15}$ Biographisches Lexicon, etc., 3rd ed., Munich, Urban \& Schwarzenberg, 1962, under Roy, de, in Volume 4, p. 905. See also, G. A. Lindeboom, [The dawn of modern physiology-Henricus Regius' Physiologia (1641) and a contemporary comment, (in Dutch)], Ned. T. Geneesk., 1972, 116: 1124-1129. 


\section{The neural circulation}

mind". ${ }^{16}$ He supported Descartes enthusiastically and was the first openly to confess Cartesian physics. ${ }^{17} \mathrm{He}$ is remembered in the history of hydraulics for an early account of capillarity, and he was the first to describe in print the "inverted syphon" experiment. ${ }^{18}$

Regius' account of the neural circulation appears in his book Fundamenta physices of $1646,{ }^{19}$ but before examining it, some knowledge of the two seventeenth-century theories of nerve function is necessary. First, there was a physical theory whereby the nerve was thought analogous to the vibrating cord of a musical instrument, later to be associated with Newtonian ether. ${ }^{20}$ Second, was the much more popular idea that the nerves were hollow and that along them travelled a substance, either animal spirits or nerve fluid, which was prepared in the brain from the blood and subserved motor and sensory functions. It is this theory that is the basis of Regius' neural circulation, which he described as follows: "The animal spirits, after being distributed from the brain to the whole body, are dissipated partly by insensible transpiration and partly by entering the veins, where they mingle with the blood and return with it to the heart. From there they proceed to the brain and again into the nerves." 21

Thus, to use the immortal words of Harvey, the nerve substance had ". . . a certain movement, as it were in a circle. ..."22 Regius proved this to his own satisfaction, by an analogy with the slug. He put one in a bottle and observed that when it moved, bubbles could be seen in its body moving from tail to head (Figure 2). When it stopped, they stopped. It is important to observe that the animal was crawling on the glass of the bottle and thus revealed its sole or foot to the observer. Regius concluded as follows: ". . . a kind of circulation of spirits seems to occur in the movement of the slug, so that they pass from the tail through the belly to the head, and return from the head along the back to the tail, from there to proceed again to the head." ${ }_{23}$

This all seems very strange and the extensive literature on the slug makes no

16 'Letter to Dinet', in, Elizabeth S. Haldane and G. R. T. Ross, The philosophical works of Descartes rendered into English, New York, Dover, 1955, Volume 2, p. 361 . He is also described as "skilful and diligent".

${ }^{17}$ Marie Boas, 'The establishment of the mechanical philosophy', Osiris, 1952, 10: 412-541, see p. 451. Although at first Regius was an ardent disciple of Descartes who taught his philosophy throughout Holland, he later refuted certain Cartesian doctrines and a bitterness developed between them. See, Karl E. Rothschuh, 'Henricus Regius und Descartes. Neue Einblicke in die frühe Physiologie (1640-1641) des Regius', Arch. hist. Sci., 1968, 21: 39-66. See also, ibid. (1955), pp. 361-362.

${ }^{18}$ E. C. Millington, 'Studies in cohesion from Democritus to Laplace', Lychnos, 1944-1945, pp. 55-78, see p. 63.

${ }^{10}$ H. Regius, Fundamenta physices, Amsterdam, L. Elzevir, 1646, pp. 225-226 and p. 232. The second edition, published in 1654, was entitled Philosophia naturalis, and the third of 1661, with the same title, was much enlarged. The passages relating to the neural circulation remained unchanged throughout the three editions.

so George Thomson accepted this theory and rejected the idea of animal spirits in the nerves: The anatomy of human bodies, London, R. Ware, et al., 1734, pp. 135-150. Bryan Robinson, ( $A$ treatise of the animal oeconomy, 2nd ed., Dublin, S. Powell for G. Ewing \& W. Smith, 1734, pp. 83-104) held similar views.

21 Op cit., note 19 above, pp. 225-226.

22 William Harvey, Exercitatio anatomica de motu cordis et sanguinis in animalibus, Frankfurt, W. Fitzer, 1628, p. 41. Gweneth Whitteridge discusses the problems of translating the portion of Chapter 8 in which this passage occurs: William Harvey. An anatomical disputation concerning the movement of the heart and blood in living creatures, Oxford, Blackwell, 1976, pp. xli-li.

${ }^{23}$ Op. cit., note 19 above, p. 232. 


\section{Edwin Clarke}

reference to intra-corporeal bubbles. ${ }^{24}$ At this point the problem could be abandoned, and the observation attributed to Regius' pre-conditioned mind. However, there are occasions when incomprehensible passages of a text can be elucidated by a technique known as "practical history". ${ }^{25}$ This simply means re-creating the experimental situation facing the original observer. In the present case, it was only a matter of putting a garden slug on a piece of glass and observing it in motion from below, just as it is depicted in Figure 3. The solution is immediately obvious: the "bubbles" derive from the slug's mode of propulsion, which is based on metachronal rhythm producing a wave-like motion. ${ }^{26}$ It is also partly an optical effect, and one sees dark areas rounded at the front which appear to proceed along the slug's foot from tail to head, but only, of course, when it is moving. They give the appearance of being actually in the body of the animal, and it is easy to see how Regius was deceived. They seem to disappear at the head and reappear at the tail, so that his assumption that they moved continuously in a circle, although incorrect, is also understandable.

Similar observations were reported by Walter Charleton (1620-1707). ${ }^{27} \mathrm{He}$ was President of the Royal College of Physicians of London from 1689 to 1691, Harveian Orator thrice (1680, 1702, and 1705), Harveian Librarian, one of the original Fellows of the Royal Society, being elected in 1663, and physician-in-ordinary to Charles I and Charles II. Charleton recommended "a large grey Snail", 28 in which propulsion is exactly as in the slug, and repeated Regius' interpretations of what he saw, but in addition he discussed the analogy with the snail. He pointed out that knowledge of motion in a higher animal can be derived from the observation of one less perfect, and he concluded: “. . . it seems not improbable, that as the progressive Motion of Reptils is performed by the help of an Aerial Substance [i.e. the bubbles], so likewise our muscular Motion is made by the help of a spirituose Influx from the Brain into the Nerves and Muscles."29

One should not be too scathing about this use of a lowly creature to elucidate a human puzzle. It was in the best Aristotelian tradition, and the only way to understand his account of the human brain, for example, is to dissect the turtle, upon which he seems to have based his findings. Thus by the use of practical history, the difficulties

24 For example, Libbie Henrietta Hyman, The invertebrates. Volume VI. Mollusca I, New York, McGraw-Hill, 1967, pp. 548-650, and the voluminous literature referred to.

${ }^{25}$ Edwin Clarke and J. G. Bearn, 'Practical history. The role of experimentation in medical history', in Edwin Clarke (editor), Modern methods in the history of medicine, London, Athlone Press, 1971, pp. 358-375.

${ }^{26} \mathrm{H}$. W. Lissmann, 'The mechanism of locomotion in gastropod molluscs. I. Kinematics', $J$. exper. Biol., 1945, 21: 58-69. A much earlier work (Martin Lister, Exercitatio anatomica in qua de "Cochleis", maxime "Terrestribus" \& "Limacibus", agitur, London, S. Smith \& B. Walford, 1694, pp. 152-160) also discussed the propulsion of gastropods. See also, Adolf Herfs, 'Studien über die Verteilung und die ökologische Bedeutung des Flimmerepithels auf der Haut unserer Land- und Süsswassergastropoden', Verh. Naturh. Ver. preuss. Rheinl., 1925, 82: 21-32, from which Fig. 3 is reproduced (Abb. 3$)$.

${ }^{27}$ Humphry Rolleston, 'Walter Charleton, D.M., F.R.C.P., F.R.S', Bull. Hist. Med., 1940, 8: 403-416; Lindsay Sharp, 'Walter Charleton's early life 1620-1659, and relationship to natural philosophy in mid-seventeenth century England', Ann. Sci., 1973, 30: 311-340.

${ }^{28}$ Walter Charleton, Enquiries into human nature, in VI. anatomical praelections in the New Theatre of the Royal Colledge of Physicians in London, London, M. White for R. Boulter, 1680, p. 500.

29 Ibid., pp. 500-501. 


\section{The neural circulation}

encountered in the description can be resolved.30 Harvey used a variety of animals, many of them "slow-blooded", as Dr. Whitteridge appropriately calls them, but for obvious reasons in his case. ${ }^{31}$ Malpighi saw the capillaries in the frog, ${ }^{32}$ and Leeuwenhoek the red blood cell in the tadpole. ${ }^{33}$ In 1795 Johnstone was testing drugs on snails and extrapolating to man, ${ }^{34}$ and it is well known that this type of uncritical transference has not been entirely confined to earlier centuries. A history of the great variety of long-suffering experimental animals would make a useful study, so far neglected. In passing it should be mentioned that quite recently the snail has become a popular experimental animal for basic research on the development of the nervous system and on behaviour. ${ }^{35}$

Regius' circulatory system of 1646 survived for about 100 years, because in Boerhaave's Academical lectures of 1743 we find a description of it and the comment: ". . . so that there seems to be a Circulation of the nervous Juice not unlike that of the Blood and other grosser Humours of the Body." 36

\section{Factors influencing Regius}

There appears to have been at least five scientific factors which could have influenced Regius in the creation of his concept of neural circulation. They are as follows:

(i) The first is the only one he mentioned, and this is the analogy with the slug.

(ii) The second could have been his researches on hydraulics, but he made no reference to them when describing the circulation in the nerves.

(iii) However, the third, the analogy with the circulation of the blood, is of undoubted significance. Regius, like Descartes, was an enthusiastic supporter of Harvey, and he was fully committed to the new physiology. ${ }^{37}$ Here, the argument by analogy proceeds as follows, although Regius presumably did not adopt this formal approach. A set of phenomena $A$ is like a set $B$ with respect to properties $\mathrm{x}$ and y. But $A$ also has property $\mathrm{z}$ and it is highly likely that $B$ will have it also. Thus the cardiovascular

${ }^{20}$ Edwin Clarke and Jerry Stannard, 'Aristotle on the anatomy of the brain', J. Hist. Med., 1963, 18: 130-148.

21 Gweneth Whitteridge, William Harvey and the circulation of the blood, London, Macdonald, 1971, p. 97: "slow-blooded creatures". Of the animals dissected by Aristotle fifty-nine per cent were fishes, reptiles, or invertebrates (Thomas East Lones, Aristotle's researches in natural science, London, West, Newman, 1912, pp. 102-106). Volcher Coiter also employed all kinds of amphibia: Externarum et internarum principalium humani corporis partium tabulae, etc., Nuremburg, Theodor Gertatzen, 1572, p. 124.

s2 Luigi Belloni (editor), Marcello Malpighi. De pulmonibus, Messina-Palermo, Fondazione della Società Italiana di Istochemica, etc., 1958. From Malpighi's De pulmonibus. Epistola altera, Bologna, J. B. Ferroni, 1661.

'A. van Leeuwenhoek, 'More microscopical observations', Phil. Trans., 1674, 9: 23-25.

s James Johnstone, Medical essays and observations, with disquisitions relating to the nervous system, Evesham, J. Agg, 1795, pp. 155-157.

s6 Arnold R. Kriegstein, Vincent Castellucci and Eric R. Kandel, 'Metamorphosis of Aplysia californica in laboratory culture (development/neurobiology/behavior)', Proc. Nat. Acad. Sci. U.S.A., 1974, 71: 3654-3658.

s6 Dr. Boerhaave's academical lectures on the theory of physic, etc., London, W. Innys, 1743, Volume 2, p. 313.

"7 He defended Harvey by engaging in violent, but effective, polemics against Dr. James Primerose, Harvey's chief British opponent. As Dr. Whitteridge puts it, “. . . He [Primerose] denies everything but refutes nothing ..." (Whitteridge, op. cit., note 31 above, p. 150). 


\section{Edwin Clarke}

and nervous systems have certain properties in common, such as a substance contained in hollow tubes. But it is known that the blood circulates through the blood vessels, and it is therefore possible that the animal spirits or nerve fluid will likewise circulate, in this instance through the nerves.

The physiological concept of circulation is redolent with analogies and "analogical acts", some of which were used by Harvey, and, therefore, must have influenced Regius. As is well known, thanks especially to the illuminating studies of Pagel, ${ }^{38}$ the symbolism of the circle was a potent factor in Harvey's reasoning, and it is clear that he had been affected by several earlier analogical assertions of the circular motion of the blood, as probably had been Regius. First, there is the classic one, between events in the macrocosm, or universe, and similar events in the microcosm, the human body. For example, there is Aristotle's analogy between the movement in a circle of water that rises as vapour and descends as rain, and the circular motion of blood in man. ${ }^{39}$ Likewise Aristotelian cosmology provided a fruitful analogy between the circuits of celestial bodies and circular motion in man. There was also a chemical analogy, whereby blood was thought to be distilled and perfected. ${ }^{40}$ The cyclical pattern in generation, which Harvey observed, is also to be noted. ${ }^{41}$ Indeed, the method of describing circulation as a biological phenomenon is analogical rather than inductive.42

Moreover, the circle continued to be significant well into the seventeenth century. There was Riolan's third, or coronary, circulation of 1648,43 and the lymphatic circulation, which was revealed in the 1650 s.4 ${ }^{44}$ Pagel draws attention to the circulation of the bile described by Reverhost in 1696,45 and points out that, ". . . Indeed the conviction that everything should move in circles led to interesting and scientifically correct observations and experiments concerning the movement in a circle of fluids other than blood. . .."46

However, this statement is not true as regards the neural circulation, to which Pagel makes no reference. In fact, it seems to have been referred to only once before, briefly. ${ }^{47}$ Riolan summed up tersely the position concerning additional circulatory

${ }^{88}$ Walter Pagel gives a fascinating account of Harvey's circular symbolism and those who had used it before him: Walter Pagel, William Harvey's biological ideas. Selected aspects and historical background, New York, Hafner, 1967, pp. 82-124. See also, his paper, 'The philosophy of circlesCesalpino-Harvey. A penultimate assessment', J. Hist. Med., 1957, 12: 140-157, and his New light on William Harvey, Basle, Karger, 1976, pp. 20-21, 37-41.

80 Aristotle, De partibus animalium, translated by William Ogle, in, J. A. Smith and W. D. Ross, The works of Aristotle, Oxford, Clarendon Press, 1912, Volume 5, 653a, 4-10.

${ }^{20}$ Walter Pagel, 'William Harvey and the purpose of the circulation', Isis, 1951, 42: 22-38.

11 Pagel (1967), op. cit., note 38 above, p. 84.

12 Peter M. Jucovy, 'Circle and circulation: the language and imagery of William Harvey's discovery', Persp. Biol. Med., 1976, 20: 92-107, see p. 102.

${ }^{43}$ William Harvey, The circulation of the blood. Two anatomical essays, etc., translated by Kenneth J. Franklin, Oxford, Blackwell, 1958, pp. 23 and 117. See, D. Evan Bedford, 'Harvey's third circulation. De circulo sanguinis in corde. The Harveian Oration in 1968', Br. med. J., 1968, iv: 273-277.

"see, for example, Nellie B. Eales, 'The history of the lymphatic system, with special reference to the Hunter-Monro controversy', J. Hist. Med., 1974, 29: 280-294; and Pietro Franceschini, De lactibus sive lacteis venis novo invento Gasparis Asellii, Milan, Episteme Editrice, 1972, pp. v-xxvi.

45 Mauritius van Reverhorst, De motu bilis circulari ejusque morbus, [Dissertatio anatomico-medica inauguralis], Leyden, Abraham Elzevir, 1692.

16 Pagel (1967), op. cit., note 38 above, p. 120.

"I Edwin Clarke, 'The doctrine of the hollow nerve in the seventeenth and eighteenth centuries', 


\section{The neural circulation}

systems: "He who admits the one circulation, cannot repudiate another."48

(iv) The fourth influence on Regius was that of Descartes and his mechanistic philosophy, based on his analogy of the body with a machine. He added to the model of nerve function by postulating valves in the nerves, which regulated the flow of the animal spirits. ${ }^{49}$ Clearly he was making an analogy with the valves of the veins in Harvey's circulatory system. Regius accepted them, and Willis mistakenly gave him the credit for the modification, at the same time making another analogy, suggesting that the valves were little doors, like those in musical instruments. ${ }^{50}$ However, Descartes made no reference to a nerve circulation, ${ }^{51}$ although some have seen it in the afferent and efferent limbs of the reflex, a concept that he was the first to describe, albeit in a primitive fashion. ${ }^{52}$ The statement of Aristotle that all motion is based on a cyclical repetition of pushing and pulling would also be influential here, ${ }^{53}$ and likewise the to-and-fro movement akin to Aristotle's triangular motion, referred to by Harvey when discussing the problem of motor and sensory function in the same nerve. ${ }^{54}$

(v) The fifth and final influence acting on Regius would be the contemporary knowledge of the nervous system, readily available to him, and also to others during the 100 years' span of the theory. To postulate a circulation in the nervous system analogous to that of the cardiovascular system, the following components are essential: (a) a substance analogous to the blood; (b) channels analogous to the blood vessels; (c) a pump analogous to the heart; (d) a nutritional function analogous to the arteries and their blood. All these were to be found in the medical literature of the seventeenth and eighteenth centuries.

(a) The substance in the nerves. The notion of animal spirits comes from the Ancient

in, Lloyd G. Stevenson and Robert P. Multhauf (editors), Medicine, science and culture. Historical essays in honor of Owsei Temkin, Baltimore, Md., The Johns Hopkins University Press, 1968, pp. 123-141, see pp. 129-131.

4" Harvey (1958), op. cit., note 43 above, pp. 23 and 117.

10 Treatise of man. René Descartes, French text with translation and commentary by Thomas Steele Hall, Cambridge, Mass., Harvard University Press, 1972, pp. 26-29 and 18-22; 112 and 105. ${ }^{50}$ Thomas Willis, 'Of muscularly motion', in, Dr. Willis's practice of physick, being the whole works of that renowned and famous physician, London, T. Dring, C. Harper \& J. Leigh, 1684, p. 39. He states, "... The most learned Regius . . . supposes in the Nerves some little doors, like those which are found in musical Organs. ..."

${ }^{51} \mathrm{He}$ does not mention it in any of his writings nor do his commentators, such as Auguste Georges-Berthier, 'Le mécanisme cartésien et la physiologie au XVIIe siècle', Isis, 1914-1919, 2: 37-89; A. Souques, 'Descartes et l'anatomo-physiologie du système nerveux', Rev. neurol., 1938, 70: 221-245; H. Dreyfus-le-Foyer, 'Les conceptions médicales de Descartes', Revue de Metaphysique et de Morale (Paris), 1937, 44: 237-286.

52 F. Fearing, 'René Descartes. A study in the history of theories of reflex action', Psychol. Rev., 1929, 36: 375-388; Edwin Clarke and C. D. O'Malley, The human brain and spinal cord. A historical study illustrated by writings from Antiquity to the twentieth century, Berkeley, University of California Press, 1968, pp. 329-333.

s2 Pagel (1976), op. cit., note 38 above, p. 152, citing Aristotole's De anima, 433 b.25: “.. . . For everything is moved by pushing and pulling. Hence just as in the case of a wheel, so here there must be a point which remains at rest, and from that point the movement must originate". (De anima, by J. A. Smith, in W. D. Ross (editor), The works of Aristotle, Volume 3, Oxford, Clarendon Press, 1931).

ss Gweneth Whitteridge, William Harvey De motu locali animalium 1627, Cambridge, for the Royal College of Physicians by the University Press, 1959, pp. 100 and 101. 


\section{Edwin Clarke}

Greeks and it was accepted throughout the seventeenth century. ${ }^{55}$ In the eighteenth century a nerve fluid or juice or an etherial substance was considered more likely. ${ }^{56}$ However, the general concept of something moving along the nerves lasted until the end of the eighteenth century, and even when electricity took over there was an overlap, because at first it was thought to be a fluid. ${ }^{57}$ The animal spirits or nerve fluid were produced in the brain, and here the analogy was with an alembic which provided a rarified distillate of the blood, the nerve substance. ${ }^{58}$

Different places in the brain for this process to take place were suggested, the most popular being the cerebral cortex. For this purpose the brain was thought to be a gland, again an idea originating with the Greeks, ${ }^{59}$ and persisting well into the eighteenth century, in part due to a false analogy made by Malpighi. He made it between the glandular organs, the structure of which was to some extent known, and the brain, the structure of which was quite unknown. Influenced also by the traditional notion of the brain as a gland, he found what he was looking for: gland-like bodies in the cerebral cortex. ${ }^{60}$ Unfortunately he was deceived by an artefact, because these "bodies" were areas of avascular cortex delineated by capillaries, an enigma also solved by "practical history"."1

According to Descartes the animal spirits were composed of very small bodies, and his analogy was that they move "... like the particles of a flame which issue from a torch. ..."62 They were considered to be the most subtle and finest constituent of the blood, and were almost universally accepted, for as one author put it, "We cannot imagine that anyone can either doubt of the existence of these Animal Spirits, or that they serve for Motion and Sense. . . ."63

The etherial material and the nerve fluid or juice postulated in the eighteenth century were also widely accepted. At the end of the hundred years under review, Browne Langrish, in his Croonian Lecture of 1748 given at the Royal College of Physicians of London, could claim with assurance that, ". . . the Existence of an aethereal Medium in the Nerves is past all manner of Doubt;...". 64 Moreover the great Boerhaave lent his authority to the concept, and in so doing invoked an analogy with other circulatory systems. He stated: "In the same manner therefore as the arterial Blood

${ }^{55}$ This is discussed in an excellent paper by Friedrich Solmsen, 'Greek philosophy and the discovery of the nerves', Museum Helveticum, 1961, 18: 150-167 and 169-197.

${ }^{56}$ See Clarke, op. cit., note 47 above. Claude Nicolas le Cat deals at length with the nerve fluid and the way in which it induces muscle movement, in, Traité de l'existence; de la nature et des propriétés du fluide des nerfs, et principalement de son action dans le mouvement musculaire, etc., Berlin, [no publisher], 1765, pp. 3-132.

${ }^{57}$ See, Roderick W. Horne, 'Electricity and the nervous fluid', J. Hist. Biol., 1970, 3: 235-251.

ss See for example, Willis, op. cit., note 50 above, 'The anatomy of the brain', p. 72.

${ }^{59}$ Hippocrates, 'Des glandes', 10, in E. Littré, Oeuvres completes d'Hippocrate, etc., Paris, J. B. Baillière, 1853, Volume 8, pp. 564 and 565.

${ }^{60}$ Marcello Malpighi, 'De cerebri cortice', in De viscerum structura exercitatio anatomica, Bologna, J. Monti, 1666, pp. 50-72.

"1 Edwin Clarke and J. G. Bearn, 'The brain "glands" of Malpighi elucidated by practical history', J. Hist. Med., 1968, 23: 309-330.

62 'The passions of the soul', in, Haldane and Ross, op. cit., note 16 above, Volume 1, p. 336.

${ }^{63} \mathrm{John}$ Baptist Verduc, $A$ treatise of the parts of a humane body, etc., now made English by J. Davis, London, W. Turner, 1704, p. 170.

s4 Browne Langrish, The Croonian Lectures on muscular motion [for 1747], London, C. Davis, 1748 , p. 42, XCVIII. 


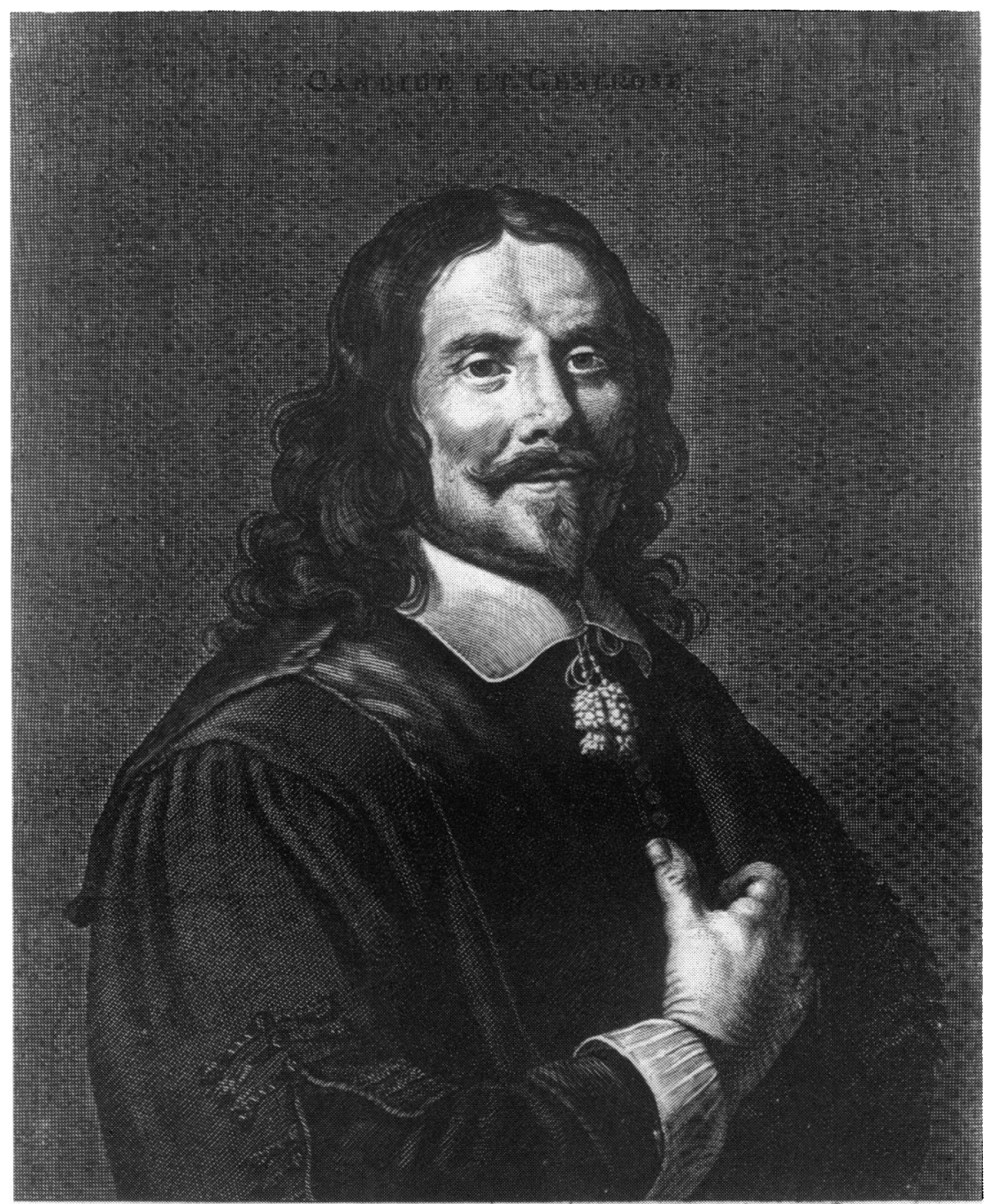

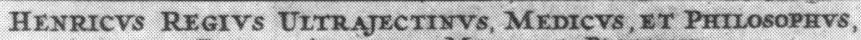

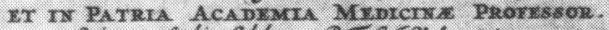

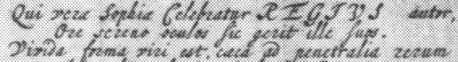

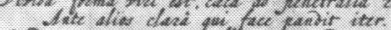

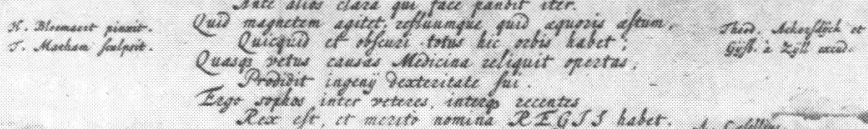

Figure 1.

Henricus Regius (1598-1679). Engraving by T. Matham after M. Bloemat, [n.d.]. (Reproduced by kind permission of the Wellcome Trustees.) 


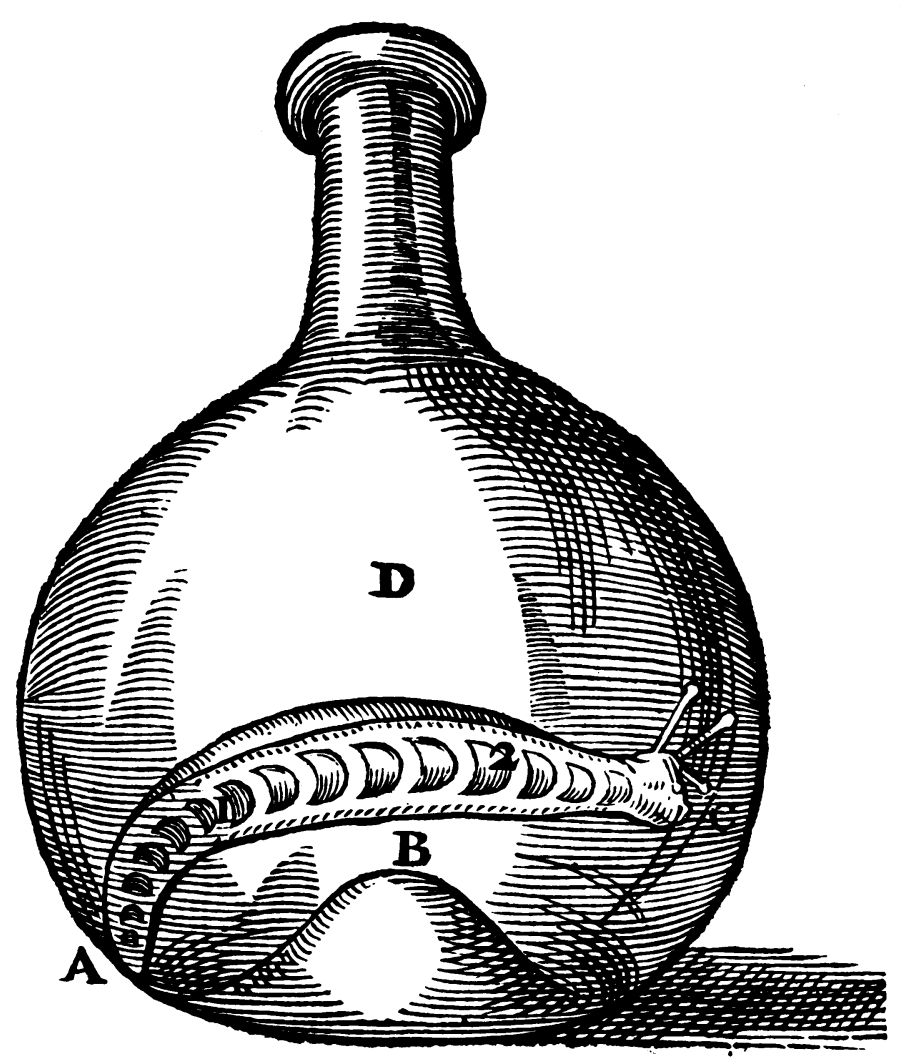

Figure 2.

Regius' illustration of a slug (ABC) in a glass vessel (D) showing its sole. Bubbles (1 and 2) containing spirits proceed from the tail A to the head C. (From his Philosophia naturalis, Amsterdam, L. Elzevir, 1654 , p. 320 . See Note 19.)

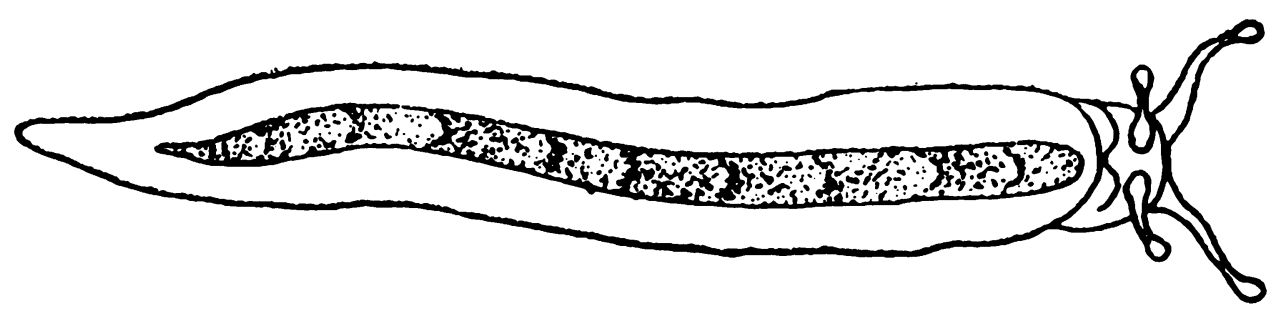

Figure 3.

The sole of the slug seen from below. (Herfs, 1925, see Note 26.) 


\section{The neural circulation}

and Lymph are perpetually distributed or moved into all the vascular Parts of the Body, so we also understand that the Juice separated by the Cortex of the Brain and Cerebellum is continuously propell' $d$ from thence through the Nerves. ..."

It is fascinating to trace the notion of nerve function over the centuries. ${ }^{68}$ The basic assumption of a substance moving along the nerves remained the same, because it seemed so clearly to be correct. To earlier minds there could be no dispute: cutting a nerve produces loss of function distally, obviously due to the interruption of centrifugal flow, just as when an artery is ligated. The name of the nerve substance changed over the years, and as new physical and chemical forces were discovered, so they were applied to nerve function. The idea acted, therefore, rather like a mirror of advances in science, or a barometer of changing scientific opinion.

(b) Conducting channels. The second pre-requisite for a neural circulatory mechanism is a system of tubes, analogous to blood vessels. That is, the nerves had to be hollow, or at least capable of allowing the nerve substance to pass along them. Like the idea just discussed, the history of the hollow nerve is one of the longest of all medical concepts. It began about 500 B.c. and lasted almost to the end of the eighteenth century. ${ }^{67}$ The influence of Aristotle's concept of nerves arising from the beart as arteries, gradually losing their lumens and becoming solid as they passed peripherally ${ }^{68}$ may have had some influence, for Cesalpino ${ }^{69}$ subscribed to it and it was still being discussed in the mid-seventeenth century. ${ }^{70}$ Many analogies or "analogical acts" were applied to the hollow nerve. Thus, the ones leaving the brain were thought to be analogous with the excretory ducts of a gland, ${ }^{71}$ or with a river system, or with a musical instrument. ${ }^{72}$ However, Descartes' analogy is the best known. ${ }^{73} \mathrm{He}$ considered them analogous to the water-pipes and other hydraulic mechanisms in the fountains and grottoes of the royal gardens at St. Germain-en-Laye. Several authors pointed out that the progression of a nerve's contents through its lumen was derived from the force of the heart and arterial contraction. ${ }^{74}$

Throughout the period 1650 to 1750 , unqualified hollowness was claimed by many, and artists depicted this in their drawings. ${ }^{75}$ They were, however, illustrating an idea

os Boerhaave, op. cit., note 36 above, p. 313.

6s Clarke and O'Malley, op. cit., note 52 above, pp. 138-259.

7 Clarke, op. cit., note 47 above.

o8 Historia animalium, 515 a. 28-35, in, Historia animalium by D'Arcy Wentworth Thompson, in, J. A. Smith and W. D. Ross (editors), The works of Aristotle, Oxford, Clarendon Press, 1910, Volume 4. It should be noted, however, that Aristotle is using the word "neuros" which for him meant sinew and tendon as well as nerve.

- Andrea Cesalpino, Tractationum philosophicarum tomus unus . . Quaestionum peripateticarum libri $V$, Geneva, Vignon, 1588, Col. 516: “. . . the heart is not only the origin of all the veins but also of the nerves".

70 Jacobus Berengarius, Mikrokosmographia [Greek]: or a description of the body of man, etc., London, L. Chapman, 1664, p. 199. This is a translation of Berengario's Isagogae, first published in Bologna in 1522.

11 Joseph de la Charrière, Anatomie nouvelle de la tête de l'homme, etc., Paris, D. Hortemels, 1703, Chap. XXVII, pp. 264-265 and 257.

72 Willis, op. cit., note 50 above, pp. 124 and 126.

73 Descartes, op. cit., note 49 above, pp. 21-22 and 13-14.

74 For example, Boerhaave, op. cit., note 36 above, pp. 315-316 and 327.

${ }^{75}$ For example, Theodor Craanen, Tractatus physico-medicus de homine, etc., Leyden, P. Vander, 1689, Tab. XVII, facing p. 400; and H. Boerhaave, Institutiones medicae, Leyden, T. Haak, et al., 1734, p. 91. 


\section{Edwin Clarke}

not an anatomical fact, so that art was being prostituted to theory. Despite advances in macroscopical and microscopical anatomy, the hollow nerve notion persisted, and it provided an excellent example of how anatomy can be subjected to theory or in other words, how function can dictate concepts of form. As just noted, the idea of nerve function based on a substance flowing in nerves seemed incontestable. Therefore, the nerves had to have cavities, even if they could not be seen. Here an analogy helped: in a tree trunk no conduits can be detected and yet water obviously ascends through it to the leaves. ${ }^{76}$ Riolan put it succinctly, "A Nerve is a Channel made to carry animal Spirit; and because the spirit is most subtil, therefore the Cavity is so smal, that it is not discernable." ${ }^{77}$ Here, both nerve and nerve substance were being made to fit the theory.

A further argument was that if the nerve is not hollow, then it must be porous to allow spirits or fluid to pass. Another explanation arose when it became known that nerves are made up of filaments or fibres, for these must be hollow, like fine pipes, or as Heister described them, "real Vessels". ${ }^{78}$ In 1717 Leeuwenhoek with his remarkable microscope detected this "hollowness", but once again he was deceived by an artefact. ${ }^{79}$ The eminent Albrecht von Haller, the most outstanding medical scientist of the eighteenth century, in 1747 also pronounced the nerve filaments to be hollow, and "to function by means of the fluid in them". ${ }^{80}$ Descartes made use of the nerve filaments in a unique way. His concept of sensory and motor function as in a spinal reflex was based on an analogy reminiscent to us, but not to him, of the flushing toilet with overhead cistern. ${ }^{81}$ A painful stimulus, say to the foot, made the filaments of the nerve move so that they opened small trap doors in the walls of the cerebral ventricles. The animal spirits contained therein poured down the nerve and caused the limb to be withdrawn.

The universality of the hollow nerve theory was emphasized by Cheyne in 1733 . He claimed that "... . scarce one (except here and there a Heretick of late) has call'd this Catholick Doctrine in question ...." ${ }^{82}$ But soon, an analogy between nervous

\footnotetext{
${ }^{76}$ Pierre Dionis, The anatomy of humane bodies improv'd, etc., translated from the 3rd ed., London, H. Bonwicke, et al., 1703, p. 427.

${ }^{77}$ Jean Riolan, $A$ sure guide; or, the best and nearest way to physick and chyrurgery: etc., Englished by Nich. Culpeper, London, P. Cole, 1657, p. 27.

${ }^{78}$ Laurentius Heister, A compendium of anatomy, etc., London, T. Combes \& J. Lacy, 1721, p. 250: "... However that the Filaments of the Nerves are hollow, and that they contain the fluid commonly call'd Spirits, and therefore not entirely solid Fibres but real Vessels, to me appears undeniable. ...."

70 Antony van Leeuwenhoek, Epistolae physiologicae super compluribus naturae arcanis, Delft, Beman, 1719, Epistle 32: pp. 310-315 (letter dated 2 March 1717). See Clarke and O’Malley, op. cit., note 52 above, pp. 30-35.

${ }^{\text {so }}$ Albrecht von Haller in, Dr. Albert Haller's physiology; etc., London, W. Innys \& J. Richardson, 1754, Volume 1, p. 314: "I believe it is, therefore, certain, that the nervous fibres are hollow, and perform their offices not by their elasticity, but by the motion of their juice. . . " (Translation of Primae linae physiologiae, Göttingen, 1747.)

${ }^{81}$ Descartes, op. cit., note 49 above, pp. 34-36, and pp. 27-29.

82 George Cheyne, The English malady: or, a treatise of nervous diseases of all kinds, etc., London, G. Strahan \& J. Leake, 1733, p. 77: "The doctrine of [animal] Spirits, to explain the animal Functions and their Diseases, has been so readily and universally receiv'd from the Days of the Arabian Physicians (and higher) down to our present Times, that scarce one (except here and there a Heretick of late) has call'd this Catholick Doctrine in question. ..."
} 


\section{The neural circulation}

and electrical fluid was to be made, ${ }^{83}$ and the days of the hollow nerve theory were numbered. Nevertheless, outposts of belief persisted into the nineteenth century, and in 1825 Bogros in France was still convinced of the nerve's hollowness, and claimed that he had experimental evidence to prove it. ${ }^{84}$ Even in 1842, Gerber of Berne thought nerve filaments might be ". . . ranked among the true vessels. . . .85 (c) A pump is the third essential for a circulatory system. The analogy is now between the heart and the brain. Pulsation of the brain had been observed by the Ancient Egyptians, ${ }^{86}$ the Ancient Greeks were well aware of it, ${ }^{87}$ and Oribasius of the fourth century A.D. analysed it carefully. ${ }^{88}$ The Renaissance anatomists, however, varied in their opinion. Fallopius denied its existence, ${ }^{89}$ whereas Columbus in 1559 said, "... it is not the heart only that has a continual diastole and systole. The brain also has it. ..."90

Others made the same analogy, observing that in diastole the brain draws in blood and in systole the nerve fluid or spirits are pumped out into the nerves, just like blood out of the left ventricle.

The actual mechanism of brain motion, however, induced much controversy.91 Some thought it came from the brain, others from the dura mater. The latter was compared with the pericardium and was thought to be able to contract. Thus Baglivi considered it to be a second heart, the cor cerebri, or the heart of the brain. An additional mechanism was added by Lancisi. ${ }^{92} \mathrm{He}$ believed that because of the muscle fibres they appeared to contain, the autonomic ganglia could contract and were therefore like little hearts acting as subsidiary pumping stations, thereby helping to circulate the nerve substance. Haller, however, effectively demolished this analogy by showing that there was, in fact, no muscle tissue in them. ${ }^{93}$

8s Sayer Walker, A treatise on nervous diseases, etc., London, J. Phillips, et al., 1796, pp. 14-22, See also, Horne, op. cit., note 57 above.

84 J. A. Bogros, Mémoire sur la structure des nerfs, Paris, E. Duverger, 1827. Paper first read at the Académie des Sciences, 2 May 1825 (Arch. gén. méd., 1825, 8 (1st series): 277-279).

${ }^{85} \mathrm{Fr}$. Gerber, Elements of the general and minute anatomy of man and the mammalia, chiefly after original researches, London, $H$. Baillière, 1842, p. 257. The first version appeared in 1840 , and this comment occurs when the author is discussing the microscopical appearances of nerve fibres.

86 James Henry Breasted (translator), The Edwin Smith surgical papyrus, Chicago, University of Chicago Press, 1930, Volume 1, pp. 165-166. The author describes the throbbing of the brain felt through a penetrating cranial wound.

${ }^{87}$ Thus, Galen, De anatomicis administrationibus, Liber IX, Caput II; (see Charles Singer, Galen on anatomical procedures, London, Wellcome Historical Medical Museum, 1956, p. 230 and elsewhere).

${ }^{88}$ Oeuvres d'Oribase ... traduit . . . par Bussemaker et Daremberg, Paris, Imprimerie Impériale, 1858, Volume 3, pp. 307-309.

${ }^{80}$ Gabriel Fallopius, Observationes anatomicae, Cologne, A. Birckmann, 1562, pp. 339-340.

${ }^{90}$ Matthaeus Realdus Columbus, De re anatomica libri $X V$, Venice, N. Bevilacqua, 1559, Liber VIII, p. 189.

${ }^{\circ 1}$ See, Max Neuburger, Die historische Entwicklung der experimentellen Gehirn- und Rückenmarksphysiologie vor Flourens, Stuttgart, F. Enke, 1897, pp. 69-96.

'2 Johann Maria Lancisi, 'De structura, usuque gangliorum', in, De motu cordis et aneurysmatibus, opus posthumum, Editio romana secunda, Rome, Typographia Palladis, 1745, pp. 405-408. See also, James Johnstone, An essay on the use of the ganglions of the nerves, Shrewsbury, printed by J. Eddowes and sold by T. Becket, et al., 1771.

${ }^{98}$ Albrecht von Haller, Elementa physiologicae corporis humani, Lausanne, F. Grasset, 1762, Volume 4, p. 203. 


\section{Edwin Clarke}

(d) The nourishing function of the nerve, analogous with the artery, is the final requirement for a circulation comparable with that of the cardiovascular system. It was a common observation that when a nerve was cut the part supplied by it withered. As disuse atrophy had not been recognized at this time, clearly the nerves, as well as having motor and sensory functions, must also nourish. Mayow was one of the first to point this out, and, being an iatrochemist, he considered that blood and nerve juice reacted to deposit suitable material for the nourishment of the parts. ${ }^{24}$ Glisson and others believed that a separate part of the nerve fluid, the succus nutritius, was carried from the mesenteric glands and mingled with the nerve juice in the brain.95 Angelo di Forte, however, reported that it went from the mouth and intestines to the brain. ${ }^{96}$ Charleton even stated that the nervous, fibrous, and membranous parts of the body were nourished by the nerves alone, and not by the blood.97

\section{The reception of Regius' neural circulation}

These then were the possible influences acting on Regius, and his theory on the tapestry of time must be examined and evaluated against this background of contemporary knowledge. No one in his day brought it all together, but the data presented were universally available so that some of them, if not all, must have influenced Regius, as well as others who accepted a neural circulation. A few of those who agreed with Regius can be traced, including Boerhaave already quoted, but no doubt further search will reveal additional supporters. ${ }^{98}$ Those accepting the theory occasionally elaborated it. Thus St. Hilaire, Dionis, and others introduced one of the arguments Harvey had employed in support of his circulation. They thought it unlikely that the brain could manufacture sufficient animal spirits to allow a man to walk all day long, for example. Therefore, like the blood, they must go in a circle and be used again.

^ John Mayow, Tractatus quinque medico-physici, etc., Oxford, Sheldonian Theatre, 1674, 'Tractatus quintus de rachitude', p. 113.

${ }^{96}$ Francis Glisson, Anatomia hepatis, etc., London, Dugard for O. Pullein, 1654, pp. 423-424. Thomas Gibson (The anatomy of humane bodies epitomized, etc., 2nd ed., J. Heptinstall for Tho. Flesher, 1684, p. 371) reported a similar mechanism. A good survey of the various opinions on the nourishing function of nerves is in, Isbrand de Diemerbroeck, The anatomy of human bodies; etc., translated by William Salmon, London, W. Whitwood, 1694, pp. 549-551.

* Angelo di Forte, De mirabilibus vitae humanae naturalia fundamenta, Venice, B. de Vianis de Lexona, 1543, Caput I, 'De corpore humano, etc.', and Caput II, 'Qua lege, cibalis cumuli succus, perneruorum radiculas ductas, varios apparatus acquirit'.

"Walter Charlton [sic], Natural history of nutrition, life, and voluntary motion, etc., London, H. Herringman, 1659, 'Of the distribution of nourishment through the nerves', pp. 156-181. His system was more complex: the succus is produced in the glands of the mesentery, in "the three glands of the loins" and in the thymus, and is carried to the brain or cord mainly by the vagus nerve, thence to be dispensed to the whole body.

${ }^{98}$ Guernerius Rolfincius, Dissertationes anatomicae methodo synthetica, etc., Nuremburg, $M$. Endter, 1656, Liber IV, Caput XII, pp. 665-666 and 676. de Saint Hilaire, L'anatomie du corps humain, etc., Paris, J. Couterot \& L. Guerin, 1684, pp. 51-52; he refers to "Descartes and others", but not to Regius. Dionis, op. cit., note 76 above, p. 380; the rubric here is "The Animal Juice circulates as well as the Blood". Peter Paxton, Specimen physico-medicum, de corpore humano ... or, an essay concerning the knowledge and cure of most diseases afflicting human bodies, London, W. Innys, 1711, p. 179. E. J. Bertin, ('Mémoire sur la circulation du fluide nerveux', Hist. Acad. Roy. Sci., 1759, (Paris, 1765), pp. 300-324) was still seeking the neural circulation in 1765. The work by Jean Bonet, brother of the more famous Théophile, entitled Traité de la circulation des esprits animaux (Paris, 1682) could not be traced. Antonius Deusingius, Sylva-caedua jacens . . . I. De spirituum animalium genesi, motu, et usu, etc., Groningen, J. Cullen, 1665, pp. 84-103. 


\section{The neural circulation}

On the other hand there were those who refuted Regius' system, and Thomas Bartholin in particular put forward cogent reasons for rejecting it. ${ }^{90}$ Haller did not dismiss the scheme out of hand, although he admitted that there was little evidence to support it. He, in fact, wondered if left-over nerve fluid might be reabsorbed from the body cavities and returned to the brain by way of the nerves. ${ }^{100}$

\section{The sequelae of the neural circulation}

In the middle of the eighteenth century the hydraulic theory of nerve function began to falter and soon it was swept away, although relics of it persisted into the nineteenth century. ${ }^{101}$ With it went the neural circulation, but its influence persisted and helped to shape a new view of the nervous system. The seventeenth century was, without doubt, the century of the cardiovascular system. The Aristotelian omnipotence of the heart is characterized by Harvey's well-known panegyric, here in Dr. Whitteridge's elegant translation: "The Heart of all creatures is the foundation of their life, the Prince of all their parts, the sun of the microcosm, that on which all growth depends and from whence all strength and vigour flows. ..."102

But the eighteenth century was the century of the nervous system. From the early 1700 s medical opinion increasingly favoured the predominance of the brain, cord, and nerves, and the neural circulation helped in this change of emphasis. As early as 1700 , in a somewhat unlikely place, a book on The natural history of Lancashire, is the statement that, ". . . Although the Morbifick matter be lodged only in the Stomach and Bowels, yet by irritating their Nervous Membranes all the Nerves are effected, and consequently the whole Body suffers." 103

By 1776 Cullen could propose his system of "nervous power", whereby the nervous system was dominant in the body and all diseases were due to its dysfunction. ${ }^{104}$ This interpretation, together with similar ideas of German and French physicians, founded the school of neural pathology, which was one of several disease systems popular at the end of the eighteenth century. ${ }^{105}$ Its full influence has not yet been revealed, but we know it was still active in the middle of the nineteenth century. In fact, Virchow when establishing his cellular theory of disease, had to demolish what

90 Thomas Bartholin, Anatomica, ... reformata, The Hague, A. Vlacq, 1651, pp. 452-453. Another critic was William Salmon, Ars anatomica: or, the anatomy of humane bodies, etc., London, I. Dawks for D. Browne, W. Taylor \& J. Browne, 1714, p. 111.

100 Haller, op. cit., note 80 above, Para. 384, p. 202.

101 Gerber, op. cit., note 85 above. The nerve fibres, which he called "vessels", had in them the nervous fluid, with ". . . a constant, although perhaps slow change of the contents of the nerves from the centre towards the periphery, and from the periphery towards the centre", and "... precisely that which is accomplished by the heart in regard to the blood...". He made no reference to any earlier concept of neural circulation.

102 Whitteridge, op. cit., note 22 above, p. 3.

${ }^{103}$ Charles Leigh, The natural history of Lancashire, Cheshire, and the Peak, in Derbyshire, etc., Oxford, [for the author], 1700 , p. 93.

104 William Cullen, First lines of the practice of physic, etc., 2 vols., 2nd ed., Edinburgh, W. Creech \& J. Murray, 1777, was consulted. In, The works of William Cullen M.D., etc., Edinburgh, W. Blackwood, 1827, Volume 1, p. 158, he stated that the circulation of the blood ".... is, next after the function of the brain itself, the most important of the animal economy". Cullen was always reticent in discussing his doctrines and it is, therefore, difficult to find representative passages defining them.

${ }^{105}$ Gernot Rath, 'Neural pathology. A pathogenetic concept of the eighteenth and nineteenth centuries', Bull. Hist. Med., 1959, 33: 263-275. 


\section{Edwin Clarke}

he called ". . . the aristocracy and hierarchy of blood and nerve. ..."106 And yet as late as 1900 a Frenchman, de Fleury, was describing the nervous system thus, ". . . this grand apparatus . . . is the most delicate and the most important part of our organism: it is this which commands and makes the rest live and act. Nothing in the three kingdoms of nature has so high a function: here reside the vitality, the energy of each of us. It is the incarnation of the soul, its elements, so to speak, and its material aspect." 107

It could almost be from Harvey's pen, now in support of a neurocentric, rather than a cardiocentric, system.

In fact, relics of Cullen's neurocentric system, to which the notion of neural circulation contributed, are still with us today, mainly in the fringes of medicine. We hear of nerve force, nerve exhaustion, and nerve tonics to revitalize the whole constitution. There may also appear to be other links between the neural circulation and presentday knowledge. Thus we now know that axoplasmic flow exists in nerve fibres, ${ }^{108}$ but there can, of course, be no suggestion that it began with Regius' system, or that, in other words, "he was right after all" as some might say. Another latter-day neural circulation was described twenty years ago by Dr. William Gooddy in a thoughtful paper, 'The circulation of the nerve impulse'. ${ }^{109} \mathrm{He}$ also surveyed the nervous and cardiovascular system analogy, but used modern neurological and cardiological data, and he pitched his analogy at the level of the nerve fibre and the red cell. His neural circulation is based on the afferent-efferent neuronal pathways, and this type of circular motion has been noted when discussing Descartes' concept of nerve function. Perhaps the present paper only provides a historical background to Dr. Gooddy's thesis. However, as with the axoplasmic flow in this instance also, it must not be suggested that the historical, that is the neural circulation of Regius, begot the modern. However, their main feature in common is the captivating "mystery and wondrousness" as Gooddy phrases it, of the circle's endlessness.

\section{CONCLUSION}

My circuitous considerations of a circle-centred theme brings me full-circle back to Sir Norman Moore. ${ }^{110}$ In his Fitz-Patrick Lecture for 1905 he mentioned Dr. Baldwin Hamey, Junior, a Censor of the Royal College of Physicians in 1640 and a Fellow for forty-two years. Dr. Hamey noted Copernicus' theory of the earth circling the sun, that is the macrocosm, and Harvey's circulation of the blood, that is the microcosm, and he composed a graceful and appropriate epigram linking the

\footnotetext{
108 Rudolf Virchow, 'Die Einheits-bestrebungen in der wissenschaftlichen Medicin', in Gesammelte Abhandlungen zur wissenschaftlichen Medicin, Frankfurt a.M., Meidinger, 1856, p. 51, footnote 1.

107 Maurice de Fleury, Medicine and the mind, translated from the French . . . by Stacy B. Collins, M.D., London, Downey, 1900, p. 150.

${ }_{108}$ An early attempt to prove this was by Nicola Alberto Barbieri, La circulation nerveuse neuroplasmatique, Paris, Gauthier-Villars, 1911. However, the literature on this topic is now extensive, and a good summary of work up to 1974 is by Sydney Ochs, "Axoplasmic transport-energy metabolism and mechanism', in, J. I. Hubbard (editor), The vertebrate peripheral nervous system, New York, Plenum Press, 1974, pp. 47-72.

${ }_{100}$ William Gooddy, 'The circulation of the nerve impulse. A Harveian address', Lancet, 7 September 1957, ii: 451-453. See also, letter by Walther Riese in ibid., 19 October 1957, ii: 804.

110 See footnote * above, p. 291.
} 


\section{The neural circulation}

two; had he known of the postulated neural circulation he would have judged it even more appropriate. I shall be in excellent company when I end this Fitz-Patrick Lecture, as did our President his Harveian Oration, in Latin:111 tunc agit atque agimus nos rota, nosque rotam ("then are we all in a wheel and a wheel is in us all"). ${ }^{112}$

\section{SUMMARY}

The discarded theories of the past must be examined just as thoroughly as those that have survived to the present day. The neural circulation (1646 to $c$. 1750) has been superseded, but nevertheless was accepted by many, and after its decease influenced the theory of nervous system omnipotence, which held sway at the end of the eighteenth century. The concept of a circulation in the nerves was introduced by Henricus Regius (1598-1679), and the evidence in support of it is reviewed here. The analogy with the cardiovascular system had a potent etiological effect, and the use of the analogy in other aspects of medicine is discussed. By employing "practical history", Regius' use of a phenomenon seen in slugs and transferred by him to man has been elucidated.

111 Sir Douglas Black, ‘Cui bono?', Br. med. J., 29 October 1977, iv: 1109-1114.

112 Norman Moore, The history of the study of medicine in the British Isles, Oxford, Clarendon Press, 1908, pp. 2-3. 